\title{
Effects of age and gender on the pharmacokinetics of the soluble guanylate cyclase stimulator riociguat
}

Reiner Frey ${ }^{1 *}$, John Lettieri ${ }^{2}$, Andrea Nadel ${ }^{3}$, Corina Becker ${ }^{1}$, Wolfgang Mück ${ }^{1}$

From 6th International Conference on cGMP: Generators, Effectors and Therapeutic Implications

Erfurt, Germany. 28-30 June 2013

\section{Background}

Pulmonary hypertension is a disabling disease associated with high mortality [1,2]. Riociguat (under review for the treatment of pulmonary hypertension) stimulates soluble guanylate cyclase, which plays an important role in the regulation of cardiovascular tone and remodelling [3-9]. We investigated the potential effects of age and gender on the pharmacokinetics of riociguat and its primary metabolite M1 (BAY 60-4552). Safety and tolerability of riociguat were also assessed.

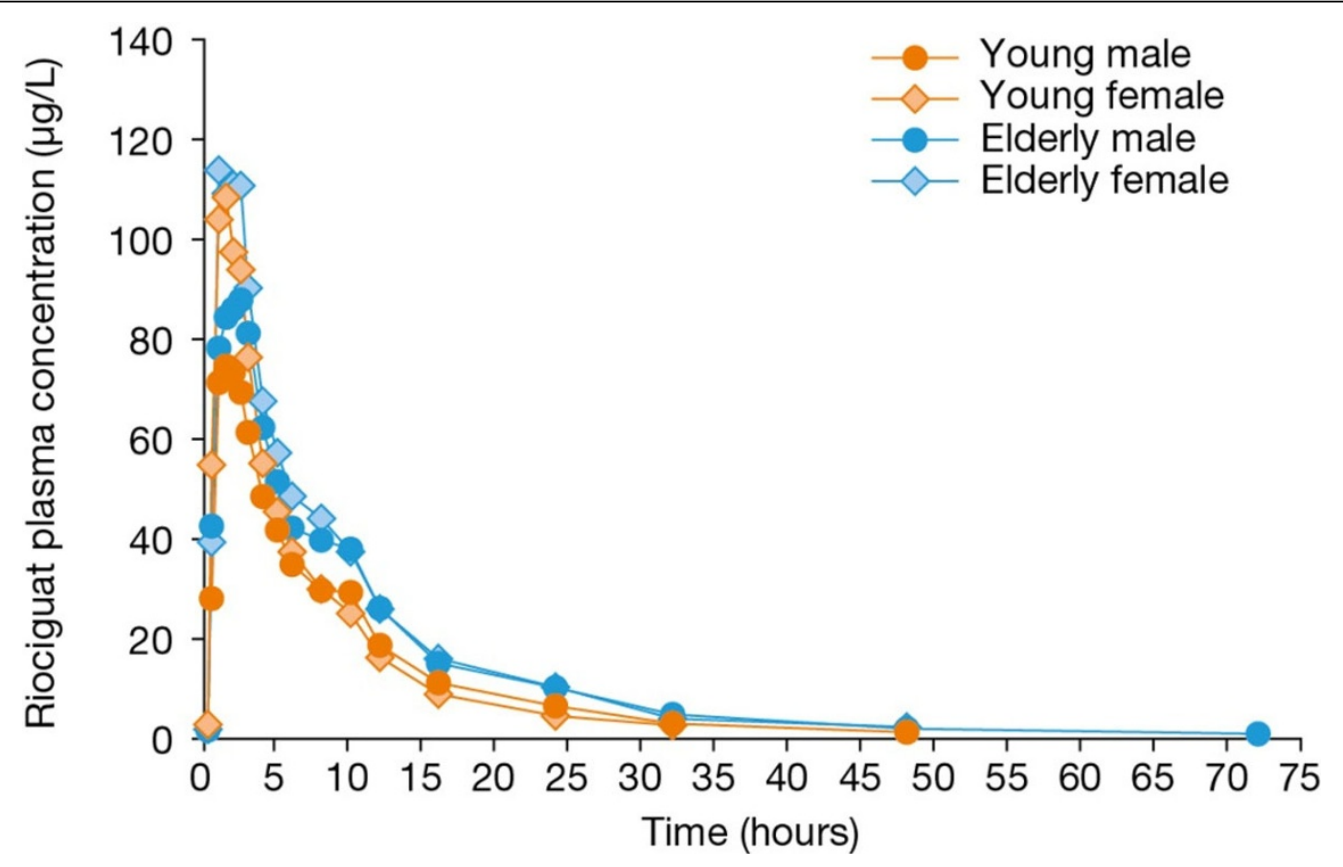

Figure 1 Mean riociguat plasma concentrations in groups of differing age and gender following administration of a single oral dose of riociguat $2.5 \mathrm{mg}$.

\footnotetext{
* Correspondence: reiner.frey@bayer.com

'Clinical Pharmacology, Bayer Pharma AG, Pharma Research Centre,

Wuppertal, Germany

Full list of author information is available at the end of the article
}

(c) 2013 Frey et al; licensee BioMed Central Ltd. This is an Open Access article distributed under the terms of the Creative Commons 
Table 1 Selected pharmacokinetic parameters of riociguat and metabolite M1 (BAY 60-4552) by age and gender following a single oral dose of riociguat $2.5 \mathrm{mg}$

\begin{tabular}{|c|c|c|c|c|}
\hline Parameter & Young female $(n=9)$ & Elderly female $(n=9)$ & Young male $(n=9)$ & Elderly male $(n=9)$ \\
\hline \multicolumn{5}{|l|}{ Riociguat } \\
\hline$A \cup C, \mu g \cdot h / L$ & $803(55)$ & $1145(36)$ & $750(58)$ & $1036(48)$ \\
\hline$C_{\max }, \mu \mathrm{g} / \mathrm{L}$ & $113(22)$ & $125(35)$ & $80.4(25)$ & $96.7(32)$ \\
\hline$A \cup C_{n o r m}, g \cdot h / L$ & $24.8(57)$ & $32.6(45)$ & $26.5(55)$ & $32.8(50)$ \\
\hline$C_{\max , \text { norm }}, \mathrm{g} / \mathrm{L}$ & $3.48(20)$ & $3.56(36)$ & $2.84(23)$ & $3.06(22)$ \\
\hline$t_{1 / 2,} h$ & $8.97(51)$ & $11.8(31)$ & $8.10(39)$ & $12.2(62)$ \\
\hline $\mathrm{CL}_{R^{\prime}} \mathrm{L} / \mathrm{h}^{\mathrm{a}}$ & $0.320(28)$ & $0.223(33)$ & $0.389(37)$ & $0.287(28)$ \\
\hline \multicolumn{5}{|l|}{ M1 } \\
\hline$A \cup C, \mu g \cdot h / L$ & $640(26)$ & $651(38)$ & $476(20)$ & $687(44)$ \\
\hline$C_{\max }, \mu g / L$ & $28.1(53)$ & $22.4(52)$ & $14.9(44)$ & $18.8(71)$ \\
\hline$A \cup C_{\text {norm }}, g \cdot h / L$ & $20.5(26)$ & $19.2(30)$ & $17.4(28)$ & $22.5(35)$ \\
\hline$C_{\text {max,norm}}, g / L$ & $0.899(51)$ & $0.661(42)$ & $0.544(51)$ & $0.615(65)$ \\
\hline$t_{1 / 2,} h$ & $16.0(34)$ & $16.7(21)$ & $14.9(28)$ & $21.3(33)$ \\
\hline $\mathrm{CL}_{\mathrm{R}^{\prime}} \mathrm{L} / \mathrm{h}^{\mathrm{a}}$ & $0.824(32)$ & $0.487(36)$ & 0.718 (39) & $0.573(44)$ \\
\hline
\end{tabular}

${ }^{a}$ Arithmetic mean (percentage coefficient of variation). All other parameters are expressed as geometric means (percentage coefficient of variation).

$A \cup C$, area under the plasma concentration-time curve from time 0 to infinity; $A \cup C_{n o r m}$, $A U C$ divided by dose per kilogram of body weight; $C_{\text {max }}$ maximum concentration in plasma; $C_{\max , \text { norm }}, C_{\max }$ divided by dose per kilogram of body weight; $t_{1 / 2,}$ terminal elimination half-life; $C L_{R}$, renal clearance.

\section{Methods}

This placebo-controlled, double-blind, single-centre study followed good clinical practice guidelines. Healthy volunteers were randomized into four groups according to age (young, 18-45 years; elderly, $64.5-80$ years) and gender: young male (YM), elderly male (EM), young female (YF), elderly female (EF). All participants received a single oral tablet of riociguat $2.5 \mathrm{mg}$ or placebo. Dense sampling was performed for pharmacokinetics.

\section{Results}

Forty-seven participants provided data for pharmacokinetic and safety analyses. Nine participants in each group received riociguat; three participants in each of the YM,
EM and EF groups and two participants in the YF group received placebo.

Age: the mean maximum concentration of riociguat in plasma $\left(C_{\max }\right)$ did not vary markedly between age groups (Figure 1). However, mean renal clearance was decreased in the elderly, and exposure (area under the plasma concentration-time curve [AUC]) to riociguat was approximately $40 \%$ higher in the elderly than in the young $(p>0.05)$ (Tables $1 \& 2)$. When normalized for body weight, the riociguat exposure $\left(\mathrm{AUC}_{\mathrm{norm}}\right)$ ratio was reduced; $\mathrm{AUC}_{\text {norm }}$ was approximately $30 \%$ higher in the elderly than in the young (Tables $1 \& 2$ ).

Gender: although riociguat mean $C_{\max }$ normalized for body weight $\left(C_{\max , n o r m}\right)$ was significantly greater in

Table 2 Comparison of selected riociguat and M1 pharmacokinetic parameters between different participant groups (ratios and $\mathbf{9 0 \%}$ confidence limits)

\begin{tabular}{|c|c|c|}
\hline Parameter & Elderly vs young ( $\mathrm{n}=18$ per group) & Female vs male ( $\mathrm{n}=18$ per group) \\
\hline \multicolumn{3}{|l|}{ Riociguat } \\
\hline AUC & $1.40(1.06-1.86)$ & $1.09(0.82-1.44)$ \\
\hline $\mathrm{C}_{\max }$ & $1.16(0.98-1.36)$ & $1.35(1.14-1.59)^{*}$ \\
\hline$A \cup C_{n o r m}$ & $1.28(0.95-1.71)$ & $0.97(0.72-1.30)$ \\
\hline$C_{\text {max,norm }}$ & $1.05(0.91-1.22)$ & $1.20(1.03-1.38)^{*}$ \\
\hline$t_{1 / 2}$ & $1.41(1.08-1.84)^{*}$ & $1.04(0.79-1.35)$ \\
\hline \multicolumn{3}{|l|}{ M1 } \\
\hline AUC & $1.21(1.00-1.46)$ & $1.13(0.94-1.36)$ \\
\hline $\mathrm{C}_{\max }$ & $1.00(0.73-1.38)$ & $1.50(1.09-2.05)^{*}$ \\
\hline$A \cup C_{n o r m}$ & $1.10(0.93-1.30)$ & $1.00(0.85-1.19)$ \\
\hline $\mathrm{C}_{\text {max,norm }}$ & $0.91(0.68-1.23)$ & $1.33(0.99-1.79)$ \\
\hline$t_{1 / 2}$ & $1.22(1.04-1.44)^{*}$ & $0.92(0.78-1.08)$ \\
\hline
\end{tabular}

${ }^{*} \mathrm{p}<0.05$ for ratio $=1$.

$A U C$, area under the plasma concentration-time curve from time 0 to infinity; $A \cup C_{\text {norm }}$ AUC divided by dose per kilogram of body weight; $C_{\text {max }}$ maximum concentration in plasma; $C_{\max , \text { norm }}, C_{\max }$ divided by dose per kilogram of body weight; $t_{1 / 2}$, terminal elimination half-life. 
women than in men, no difference in exposure was observed between genders (Tables 1 \& 2).

Across age groups, pharmacokinetics of M1 followed similar trends to those of riociguat, although differences were less pronounced (Tables $1 \& 2$ ). Compared with the combined placebo subgroups, the combined riociguat subgroups demonstrated an expected reduction in mean blood pressure and corresponding elevation of mean heart rate, waning approximately 16 hours post-dose. Three participants in the riociguat subgroups reported drug-related adverse events, one of which (hypotension) was classified as severe. All adverse events had resolved by completion of the study.

\section{Conclusion}

Age and gender had modest effects on riociguat and M1 pharmacokinetics, and the safety profile of riociguat was similar across all groups. Thus, no dose adjustment for age or gender is merited.

\section{Acknowledgements}

We thank Miguel Zinny, Maryellen Fitzgerald, Arthur LaFluer and Carolyn Maloney of ProMedica Clinical Research Center, Inc., and Christa Rotolo, Pavur Sundaresan and Arthur Mazzu of Bayer HealthCare Pharmaceutical Division for their contributions to the conduct of the study. Writing support was provided by Esther IIIman of Oxford PharmaGenesis ${ }^{\mathbf{T M}}$ Ltd, and was funded by a research grant from Bayer Pharma AG.

\section{Authors' details}

${ }^{1}$ Clinical Pharmacology, Bayer Pharma AG, Pharma Research Centre, Wuppertal, Germany. ${ }^{2}$ Clinical Pharmacology, Bayer HealthCare Pharmaceuticals, Montville, NJ, USA. ${ }^{3}$ Clinical Statistics, Bayer HealthCare Pharmaceuticals, Montville, NJ, USA.

Published: 29 August 2013

\section{References}

1. D'Alonzo GE, Barst RJ, Ayres SM, Bergofsky EH, Brundage BH, Detre KM, Fishman AP, Goldring RM, Groves BM, Kernis JT, et al: Survival in patients with primary pulmonary hypertension. Results from a national prospective registry. Ann Intern Med 1991, 115:343-349.

2. Hurdman J, Condliffe R, Elliot CA, Davies C, Hill C, Wild JM, Capener D, Sephton P, Hamilton N, Armstrong IJ, Billings C, Lawrie A, Sabroe I, Akil M, OToole L, Kiely DG: Aspire Registry: assessing the spectrum of pulmonary hypertension identified at a referral centre. Eur Respir J 2012, 39:945-955.

3. Stasch JP, Pacher P, Evgenov OV: Soluble guanylate cyclase as an emerging therapeutic target in cardiopulmonary disease. Circulation 2011, 123:2263-2273.

4. Schermuly R, Stasch JP, Pullamsetti SS, Middendorff R, Mueller D, Schlüter KD, Dingendorf A, Hackemack S, Kolosionek E, Kaulen C, Dumitrascu R, Weissmann N, Mittendorf J, Klepetko W, Seeger W, Ghofrani HA, Grimminger F: Expression and function of soluble guanylate cyclase in pulmonary arterial hypertension. Eur Respir J 2008, 32:881-891.

5. Frey R, Mück W, Unger S, Artmeier-Brandt U, Weimann G, Wensing G: Single-dose pharmacokinetics, tolerability and safety of the soluble guanylate cyclase stimulator BAY 63-2521; an ascending-dose study in healthy male volunteers. J Clin Pharmacol 2008, 48:926-934.

6. Ghofrani HA, Hoeper MM, Halank M, Meyer FJ, Staehler G, Behr J, Ewert R, Weimann G, Grimminger F: Riociguat for chronic thromboembolic pulmonary hypertension and pulmonary arterial hypertension: a phase II study. Eur Respir J 2010, 36:792-799.

7. Ghofrani H, Grimminger F, Hoeper M, Kim N, Mayer E, Neuser D, Pena J, Simonneau G, Wilkins M: Riociguat for the treatment of inoperable chronic thromboembolic pulmonary hypertension: a randomized, double-blind, placebo-controlled study (CHEST-1). Chest 2012, 142:1023A.

8. Ghofrani H, Galie N, Grimminger F, Humbert M, Keogh A, Langleben D, Kilama MO, Neuser D, Rubin L: Riociguat for the treatment of pulmonary arterial hypertension: a randomized, double-blind, placebo-controlled study (PATENT-1). Chest 2012, 142:1027A.

9. Hoeper MM, Halank M, Wilkens H, Gunther A, Weimann G, Gebert I, Leuchte $H$, Behr J: Riociguat for interstitial lung disease and pulmonary hypertension: a pilot trial. Eur Respir J 2013, 41:853-860.

doi:10.1186/2050-6511-14-S1-P23

Cite this article as: Frey et al:: Effects of age and gender on the pharmacokinetics of the soluble guanylate cyclase stimulator riociguat. BMC Pharmacology and Toxicology 2013 14(Suppl 1):P23.

\section{Submit your next manuscript to BioMed Central and take full advantage of:}

- Convenient online submission

- Thorough peer review

- No space constraints or color figure charges

- Immediate publication on acceptance

- Inclusion in PubMed, CAS, Scopus and Google Scholar

- Research which is freely available for redistribution 